\title{
Characterization and growth profile of proteolytic strain PK-4 isolated from local slaughterhouse wastewater
}

\author{
Nanung Agus Fitriyanto*, Samsul Hadi, Muhammad Imam Bahtiyar, Ragil Adi Prasetyo and Yuny Erwanto \\ Faculty of Animal Science, Universitas Gadjah Mada, Jl. Fauna No.3 Bulaksumur, Yogyakarta, 55281, Indonesia
}

\begin{abstract}
This study aims to characterize and to determine the growth profile of the proteolytic bacteria isolated from Giwangan slaughterhouse wastewater in Yogyakarta City, and to observe the optimum temperature as well as the $\mathrm{pH}$ condition for growing in the nutrient medium. Isolation of bacteria from slaughterhouse wastewater was done with a sample from 4 different locations. The isolates were then grown on a medium with a skim (at $0 ; 0.5 ; 1 \% ; 1.5$ and $2 \%$ ) and $\mathrm{pH}$ condition (at 7;8;9;10 and 11). The bacterial growth profile was measured based on the number of cells $(\mathrm{CFU} / \mathrm{mL})$, the size of the bacterial colony diameter, the diameter of the clear zone, and the proteolytic index. Strain PK4 was proved to have proteolytic activity. The characterization of Strain PK4 has shown for colony morphology with a circle shape, white color, flat edges, and convex elevation. The cell morphology was a cocci-shaped, red color, Gram-negative, and having a catalase-positive. The bacterial colony diameter, halo diameter, and proteolytic index were increased significantly $(\mathrm{P}<0.05)$ with the increase of skim milk addition. The optimal growth at the medium has reached by the addition of $1-2 \%$ Skim and $\mathrm{pH}$ alkaline ( $>7)$. It could be concluded that Strain PK4 was classified as alkalophilic and had the potency as alkaline protease producing bacteria.
\end{abstract}

\section{Introduction}

Use the biological agent in the tannery industry. Various studies have been carried out to explore the sources of alkaline protease. The enzyme from microorganisms is most attractive due to fast growth and cheap in the application. The usage of alkaline protease derived from microbes is considered as an environmentally friendly, due to it will not leave chemical residue in the environment. The alkaline protease enzyme digest soft keratin in the cells of the Malpighian layer and hair roots. Thus, the hair can be pulled up from its roots.

On the other hand, the keratinase enzyme, which belongs to the protease family, can digest various poultry feathers [1]. Various microbes that have been studied as alkaline protease producing strain are Bacillus spp., Pseudomonas spp., Geomicrobium spp., Listeria spp., Geobacillus spp., and Xenorhabdus spp. Alkaline protease-producing microorganisms could be isolated from various sources such as soil [2], wastewater [3], and mud sediments [4], the places which are characterized as high organic nitrogen content. Furthermore, the isolate can be screened to get the expected potential characteristics based on the specific activity of the substrate, the optimal $\mathrm{pH}$, and the temperature which appropriate to the environment [5]. The sequenceprocedure for purification is important to improve the quality of protease in hydrolyze protein as well as the activity of the enzyme $[6,7]$.

The development of the meat processing industry in Indonesia encourages more slaughterhouse to be built in all regions of Indonesia to provide meat that is safe, healthy, whole, and halal. On the other hand, abattoir activities also produce high organic contamination, especially protein derived from blood, urine, feces, rumen, intestinal contents, and meat excretion. The high protein content and $\mathrm{pH}$ condition of the slaughterhouse wastewater are thought to be suitable for the growth of the proteolytic bacteria. It provides an excellent opportunity to get potential indigenous bacteria as a producer of the alkaline protease enzyme that can be developed as the dehairing agent in the tannery industry in Indonesia.

\section{Materials and methods}

\subsection{The preparation of isolation medium}

Wastewater samples were taken from Giwangan Ruminant Slaughterhouse, Yogyakarta Province, Indonesia. The medium of stock solution $(100 \mathrm{~mL})$ was made by mixing $1 \mathrm{~g}$ meat extract, $1 \mathrm{~g}$ biological peptone, and $0.5 \mathrm{~mL} \mathrm{NaCl}$. The nutrient agar medium $(100 \mathrm{~mL})$ was made by adding a $1 \mathrm{~mL}$ of stock solution, with 1.5 $\mathrm{g}$ agar powder, $2 \mathrm{~g}$ of skim milk, and distillate water. The medium of pre-culture bacteria $(100 \mathrm{~mL})$ was made by adding $90 \mathrm{~mL}$ of distilled water and $10 \mathrm{~mL}$ of stock solution. The liquid medium $(100 \mathrm{~mL})$ was made by adding a stock solution with $2 \%$ skim milk. Meanwhile, the liquid medium for control was made by using a 100 $\%$ stock solution. All medium used in this study had been sterilized by autoclaving at $121^{\circ} \mathrm{C}$ for $15 \mathrm{~min}$, and

\footnotetext{
*Corresponding author: nanungagusfitriyanto@ugm.ac.id
} 
the $\mathrm{pH}$ medium was adjusted by adding $\mathrm{HCl}$ or $\mathrm{NaOH}$ before the sterilization process.

\subsection{The isolation and screening for proteolytic bacteria}

\subsubsection{The isolation}

The samples of Giwangan Ruminant Slaughterhouse were taken from 4 different locations: Wastewater from the killing box (AQ4), wastewater from the gut room $(P K 4)$, wastewater from the mixed waste of goat and sheep process of slaughtering (PL5), and wastewater from the mixed waste of cow, goat and sheep process of slaughtering (PH5). Bacterial isolation was carried out by inoculating the sample into the nutrient agar medium after the sequence of dilution. The results of each dilution at $10^{-4}, 10^{-5}, 10^{-6}$ were then taken $100 \mu \mathrm{m}$ using a micropipette, cultured using the pour plate method on the nutrient agar medium, and incubated for $72 \mathrm{~h}$ room temperature. Bacterial strains are selected based on their ability to produce protease activity, characterized by forming clear zones around bacterial colonies [8]. The selected single colony was grown in the nutrient medium. They were stored for a short time in refrigerators at $4^{\circ} \mathrm{C}$ and periodically re-culture in a new medium.

\subsubsection{Characterization of the potential indigenous bacteria}

Further characterization of the selected indigenous strain was conducted by observing the cell morphology and also colony shape using m'acroscopic and microscopic observations, as well as biochemical characterization. Macroscopically, the observed characteristics were: color, colony configuration, colony surface, and edge. Microscopically, the tests included: Gram stain, shape, and cell arrangement. Biochemical tests included: catalase activity, motility, gelatin hydrolysis, growth characterization, and environmental tolerance tested by growing the isolate on medium agar with different level of substrate concentration $(0 ; 1 ; 1.5$; and $2 \%$ skim milk) and different initial $\mathrm{pH}$ condition $(7$; $8 ; 9 ; 10$ and 11). The results of the bacterial colonies $(X)$ and the clear zone or halo diameter $(Y)$ formed were used to determine the proteolytic index $(Z)$ following [8] with the equation $\mathrm{Z}=(\mathrm{Y}-\mathrm{X}) / \mathrm{X}$. The growth characteristic assessment had done using the liquid medium that contained $2 \%$ skim milk addition and without the skim milk addition (control). The isolate was grown in the liquid medium, incubated for $48 \mathrm{~h}$ at a rotary shaker (120 rpm). The total plate count (TPC) was periodically (every $6 \mathrm{~h}$ ) measured using the Colony Forming Unit $(\mathrm{CFU} / \mathrm{mL})$ method by plating on the nutrient agar medium.

\subsubsection{Data analysis}

Bacterial isolation, identification, bacterial growth characteristic, the extracellular enzyme activity were descriptively analyzed and supported by a table or figure. The data of growth characteristics based on the different substrate and initial $\mathrm{pH}$ medium was done with triplicate replication. It was analyzed using a completely randomized complete design (Completely Randomized Design) followed by the Duncan's New Multiple Range Test (DMRT) for the differences test [9].

\section{Results and discussions}

\subsection{Isolation and characterization of the alkaline protease producer strains}

In this study, wastewater samples were taken from 4 different locations at Giwangan slaughterhouse, resulted in 4 strains, and the only one which showed proteolytic activity at the alkaline condition. Furthermore, $1 \mathrm{~mL}$ slaughterhouse wastewater was added to $9 \mathrm{~mL}$ sterile water, continued by sequence dilution, and cultivated to nutrient agar medium with $2 \%$ skim milk. After cultivated for $72 \mathrm{~h}$, the strain with a clear zone was then characterized and used for further observation. The clear zone (halo) around bacterial colonies in nutrient agar medium only occurred in the strain with the codenumber PK4. Thus it was designed as Strain PK4. That was indicated that strain PK4 has the potency for producing the extracellular proteases enzyme at the alkaline condition. The results of bacteria isolation and characterization of this study have shown in Figure 1 and Table 1.

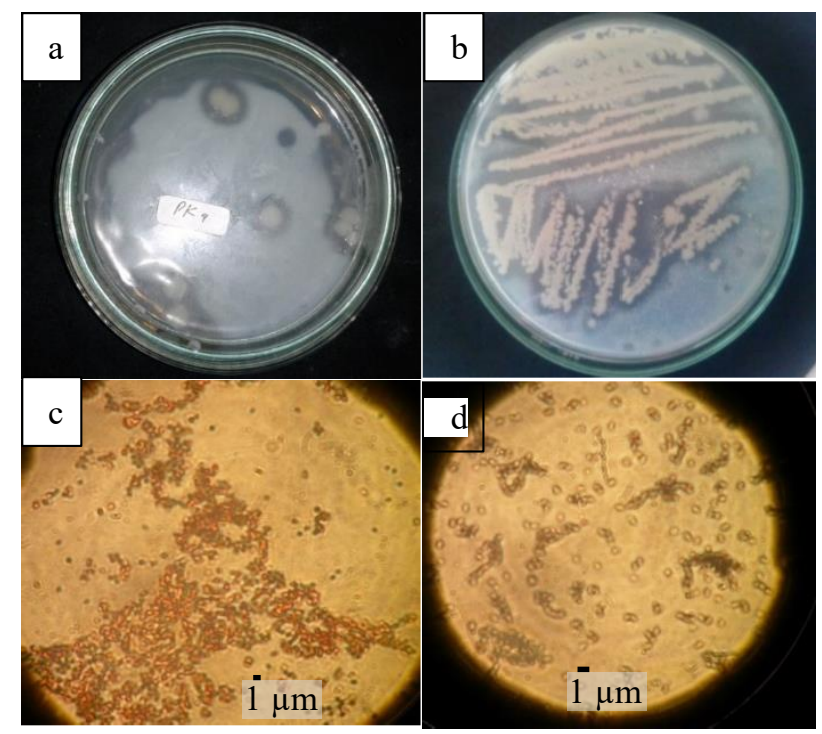

Fig. 1. (a) Strain PK4 from the first isolation shows the clear zone, (b) Purification of Strain PK4, (c) Strain PK4 cells observed with $400 \mathrm{x}$ contras microscope, (d) morphology of the cell (Cocci shape) observed with 1000 x contras microscope. 
Table 1. The Morphological characteristic of Strain PK4

\begin{tabular}{|c|c|}
\hline Characterization & Result \\
\hline \multicolumn{2}{|c|}{$\begin{array}{l}\text { Macroscopy observation of the } \\
\text { colony morphology }\end{array}$} \\
\hline Color & Yellow-White \\
\hline Configuration & Round \\
\hline Colony surface & Convex \\
\hline Edge & Flat \\
\hline \multicolumn{2}{|c|}{ Microscopy observation of the cells morpholog } \\
\hline Shape & Cocci \\
\hline Arrangement & Chain \\
\hline Gram staining & Gram-negative \\
\hline Catalase Test & Positive \\
\hline Motility Test & Motile \\
\hline Gelatin Test & Positive \\
\hline
\end{tabular}

\subsection{Growth characteristic of PK4 strain bacteria}

The growth character of Strain PK4 in the liquid nutrient medium at $\mathrm{pH} 10$ was shown in Figure 2. The growth graph during $48 \mathrm{~h}$ of observation is described in Figure 2a. There were occurred the discoloration phenomena on the mediums, which is the addition of skim milk had the cloudy white at initial observation (Figure 2b) and became the dark yellow at the end of the cultivation period (Figure 2c).

Discoloration in the skim medium is a sign of hydrolysis the casein from skims substrates by protease enzyme produced by the Strain PK4. The existence of extracellular proteolytic enzymes produced by Strain PK4 was suggested causing the casein substrate hydrolyzed into peptide and amino acid. The existence of peptides and amino acids becomes the source of Nitrogen $(\mathrm{N})$ as the essential compounds needed for cell growth and energy metabolism, which will be used together with the Carbon

(C) source available in the medium. Microbes need the availability of $\mathrm{C}$ and $\mathrm{N}$ sources in the media as a source of carbon framework to form energy and the components of metabolism for cell activity, cell maintenances, and growth. The microbial growth in the medium, including lag phases, log phases, stationary phases, and death phases. Based on the growth curve (Figure 2a), the lag phase of PK4 has occurred at the initial $24 \mathrm{~h}$, the $\log$ phase occurs at $24^{\text {th }} \mathrm{h}$ to $30^{\text {th }} \mathrm{h}$, the stationary phase occurs at $30^{\text {th }} \mathrm{h}$ to $42^{\text {nd }} \mathrm{h}$, and after $42 \mathrm{~h}$ had entered the death phase. During $48 \mathrm{~h}$ of observation, cell growth activity in the medium with the addition of skim milk was $2 \%$ were higher than the control medium. The highest cell growth of Strain PK4 was observed at $36 \mathrm{~h}$, with an average TPC yield at $5.47 \mathrm{log}$ $\mathrm{CFU} / \mathrm{mL}$, while the control was $5.41 \log \mathrm{CFU} / \mathrm{mL}$.

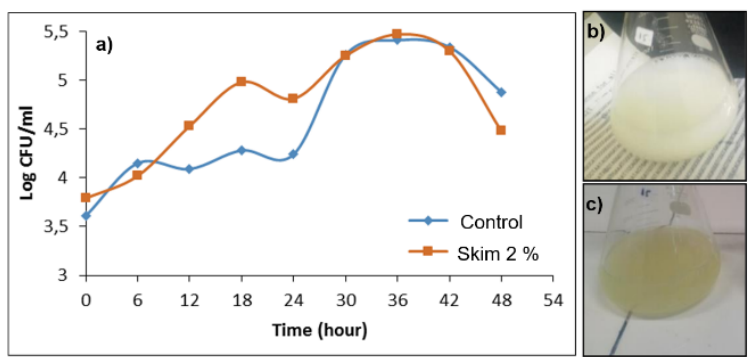

Fig. 2. (a) Growth graph of Strain PK4 (Log CFU/mL), (b) Initial medium $2 \%$ skim milk conditions $(0 \mathrm{~h}),(\mathrm{c})$ The medium with $2 \%$ skim milk after $48 \mathrm{~h}$ of cultivation period.

The growth of a microorganism, especially in the proteolytic bacteria, is mainly influenced by environmental factors such as physical-chemical factors (temperature, $\mathrm{pH}$, aeration, agitation) and substrate composition in the growing media [10]. Bacterial growth characterization in this study used agar medium with different skim milk concentration and initial $\mathrm{pH}$ medium. The treatment of differences in skim milk concentration in the medium aims to observe the optimum concentration level of the substrate that can be utilized by bacterial cells to grow and produced the protease enzymes. In contrast, the $\mathrm{pH}$ treatment aims to observe the survival potency of bacterial cells at the alkaline condition and their ability to produce alkaline protease enzymes. The characterization of growth and extracellular proteolytic enzyme produced by the strain PK4 bacteria conducted in the medium with different substrate concentrations and initial $\mathrm{pH}$ value showed in Tables 2 and 3.

Table 2. Colony diameter, the diameter of the halo, and proteolytic index from strain PK4 at the medium with different substrate concentrations.

\begin{tabular}{cccccc} 
& \multicolumn{5}{c}{ Skim milk concentration (\%) } \\
\cline { 2 - 6 } Parameter & $\mathbf{0}$ & $\mathbf{0 . 5}$ & $\mathbf{1}$ & $\mathbf{1 . 5}$ & $\mathbf{2}$ \\
\cline { 2 - 6 } & $12.5 \pm$ & $19.8 \pm$ & $25.6 \pm$ & $27.6 \pm$ & $27.2 \pm$ \\
$\begin{array}{c}\text { Diameter of the } \\
\text { colony (mm) }\end{array}$ & $0.22^{\mathrm{a}}$ & $0.90^{\mathrm{ab}}$ & $0.33^{\mathrm{b}}$ & $0.48^{\mathrm{b}}$ & $0.20^{\mathrm{b}}$ \\
& & & & & \\
$\begin{array}{c}\text { Diameter of } \\
\text { halo (mm) }\end{array}$ & - & $24.7 \pm$ & $35.5^{ \pm}$ & $38.7 \pm$ & $32.2 \pm$ \\
& & $0.88^{\mathrm{b}}$ & $0.23^{\mathrm{bc}}$ & $0.63^{\mathrm{c}}$ & $0.29^{\mathrm{bc}}$ \\
$\begin{array}{c}\text { Proteolytic } \\
\text { indexs }\end{array}$ & - & $0.38 \pm$ & $0.45^{ \pm}$ & $0.46 \pm$ & $0.14 \pm$ \\
& & $0.04^{\mathrm{b}}$ & $0.03^{\mathrm{b}}$ & $0.03^{\mathrm{b}}$ & $0.02^{\mathrm{a}}$
\end{tabular}

Noted: ${ }^{\mathrm{a}, \mathrm{b}, \mathrm{c}}$ means in the same row with different superscript differ significantly $(\mathrm{P}<0.05)$, ,(-) not observed

The measurement of colony diameter from Strain PK4 on nutrient agar medium with different skim concentrations and various $\mathrm{pH}$ conditions were shown in Table 2 and Tabel 3 . The diameter size of the colonies increased in line with the level of skim added to the medium. Based on Table 2, the diameter size of strain colonies on the control medium (skim $0 \%$ ) has not significantly different from the medium, which was given $0.5 \%$ skim milk. However, it was significantly 
increased compared to the medium with the addition of skim concentration at $1 ; 1.5$, and $2 \%$.

Table 3. Colony diameter, the diameter of the halo, and proteolytic index from strain PK4 at the medium with different initial $\mathrm{pH}$ conditions.

\begin{tabular}{|c|c|c|c|c|c|}
\hline \multirow{2}{*}{ Parameter } & \multicolumn{5}{|c|}{ Initial pH Medium } \\
\hline & 7 & 8 & 9 & 10 & 11 \\
\hline $\begin{array}{l}\text { Diameter of the colony } \\
(\mathrm{mm})\end{array}$ & $\begin{array}{l}23.6 \\
\pm 3.7^{\mathrm{a}}\end{array}$ & $\begin{array}{l}25.3 \\
\pm 6.3^{\text {ab }}\end{array}$ & $\begin{array}{l}27.3 \\
\pm 4.6^{\text {ab }}\end{array}$ & $\begin{array}{l}31.9 \\
\pm 1.0^{\mathrm{b}}\end{array}$ & $\begin{array}{l}36.1 \\
\pm 1.5^{\mathrm{bc}}\end{array}$ \\
\hline Diameter of halo $(\mathrm{mm})$ & $\begin{array}{l}25.1 \\
\pm 3.7^{\mathrm{a}}\end{array}$ & $\begin{array}{l}29.4 \\
\pm 4.3^{\mathrm{a}}\end{array}$ & $\begin{array}{l}32.1 \\
\pm 4.4^{\text {ab }}\end{array}$ & $\begin{array}{l}38.9 \\
\pm 1.0^{\mathrm{b}}\end{array}$ & $\begin{array}{l}39.6 \\
\pm 4.5^{\mathrm{b}}\end{array}$ \\
\hline Indexs of proteolytic & $\begin{array}{l}0.13 \\
\pm 0.03^{\mathrm{a}} \\
\end{array}$ & $\begin{array}{l}0.23 \\
\pm 0.05^{\mathrm{b}}\end{array}$ & $\begin{array}{ll}0.0 \\
\pm 0.03^{\text {ab }}\end{array}$ & $\begin{array}{l}0.21 \\
\pm 0.03^{\text {ab }}\end{array}$ & $\begin{array}{l}0.16 \\
\pm 0.01^{\mathrm{ab}}\end{array}$ \\
\hline
\end{tabular}

Noted: ${ }^{a, b, c}$ means in the same row with different superscript differ significantly $(\mathrm{P}<0.05)$

The measurement of the halo diameter of the Strain PK4 grown on the agar medium with different skim concentrations showed an increase linear with the higher level of skim added to the medium. The halo (clear zone) began to be observed on the medium with the $0.5 \%$ addition of skim milk. It has not significantly different than the medium that was given $1 \%$, and $2 \%$ skim. However, it was significantly different compared to the medium with $1.5 \%$ a skim. Bacterial isolates grown on medium without the addition of skim ( $0 \%$ skim $)$ did not show any clear zone formed around the colony. The highest proteolytic index occurred at the medium with the addition of $0.5,1$, and $1.5 \%$ skim milk. This result was lower than the other alkaline protease isolated from leather waste at the previous study, with the range at 2.27-2.45 of proteolytic index [4]. The formation of a clear zone around the colony occurs due to the ability of Strain PK4 secreting the protease enzyme, which can hydrolyze the casein substrate on the skim into simpler peptides, in line with the discoloration phenomenon of the medium during $48 \mathrm{~h}$ observation. In the agar medium, without the addition of skim ( $0 \%$ skim $)$, there was no halo diameter observed. It suggested there was no casein substrate, so the hydrolysis of the casein not occurred and does not show the formation of clear zones around the colony. According to [11], bacteria can hydrolyze proteins from substrates available outside of their body and use these hydrolysis products as a source of nitrogen and carbon framework in energy metabolism and cell growth.

The measurement of colony diameter the strain PK4 isolate bacterial on medium with different initial $\mathrm{pH}$ conditions (Table 3.) showed that the diameter size of bacterial colonies and halo diameter was increased linearly with the higher initial $\mathrm{pH}$ condition on the medium $(>7)$. The largest diameter size of bacterial colonies, halo diameter, and index of proteolytic occurred in this study was on the range of initial $\mathrm{pH}$ on medium at alkaline conditions 8-11. It can be assumed that the strain PK4 isolate bacterial was classified as alkalophilic and had the potency as alkaline protease bacteria. Protease enzymes may be classified into acidic, neutral, and alkaline proteases based on their optimum $\mathrm{pH}$ [12]. The $\mathrm{pH}$ range from 8 to 12 can be categorized as alkaline protease. This result was in line with the potential indigenous alkaline protease bacteria that had the optimal activity at $\mathrm{pH}>10[3]$.

\section{Conclusion}

Strain PK4 has proved to have proteolytic activity. Strain PK4 has characterized by having round shape colony, white color, flat edges, and convex elevation. The cell morphology has a cocci-shaped, red color, Gram- negative, and catalase-positive. The result in bacterial colony diameter, halo diameter, and proteolytic index were increased and had optimal activity at the medium with a concentration of $1-2 \%$ Skim and $\mathrm{pH}$ alkaline ( $>7$ ). Strain PK4 was classified as alkalophilic and had the potency as alkaline protease bacteria for further study

This research was financially supported by grant aid from the Faculty of Animal Science Universitas Gadjah Mada through Thematic Laboratory Grant.

\section{References}

1. T.G. Wandita, S. Triatmojo, J. Gumilar, N A. Fitriyanto, Asian J. Microbiol. Biotechnol. Environ. Sci. 18, 71 (2016).

2. N.A. Fitriyanto, V. Oktaria, Y. Erwanto, Rusman, T. Hayakawa, T. Nakagawa, K. Kawai, 16th AsianAustralasian Assoc. Anim. Prod. Socities Proc. 16, 1308 (2014).

3. A. Pertiwiningrum, F.D. Anggraini, N.A. Fitrianto, J. Rochijan, J. Indones. Trop. Anim. Agric. 42, 33 (2017).

4. M. Dagnaw, B. Andualem, J. Med. Plants Stud. 7, 127 (2019).

5. K.M. Sharma, R. Kumar, S. Panwar, A. Kumar, J. Genet. Eng. Biotechnol. 15, 115 (2017).

6. Y. Junaidi, A. Pertiwiningrum, Y. Erwanto, and N. A. Fitriyanto, Int. J. Bio-Science Bio-Technology 9, 89 (2017).

7. Y. Junaidi, A. Partiwiningrum, Y. Erwanto, Jamhari, L.M. Yusiati, T. Hayakawa, T. Nakagawa, N.A. Fitriyanto, Pakistan J. Biotechnol. 15, 413 (2018).

8. G. Lim, T.K. Tan, N.A. Rahim, MIRCEN J. Appl. Microbiol. Biotechnol. 3, 319 (1987).

9. R.G.D. Steel, J.H. Torrie, Prinsip Dan Prosedur Statistika (Terjemahan), PT. Gramedia Pustaka Utama, Jakarta, (1995).

10. V. Vranova, K. Rejsek, P. Formanek, Appl. Soil Ecol. 70, 23 (2013).

11. M.T. Madigan, J.M. Martinko, D.A. Stahl, D. P. Clark, Brock Biology of Microorganisms 13th Edition. Benjamin Cummings, San Francisco, (2010).

12. M. Nadeem, J.I. Qazi, S. Baig, Q.U. Syed, Turkish J. Biochem. 32, 171 (2007). 